\title{
Eponyms in dermatology linked to pigmented purpuric dermatoses
}

\section{Khalid Al Aboud', Daifullah Al Aboud², Ahmad Al Aboud ${ }^{3}$}

${ }^{1}$ Department of Public Health, King Faisal Hospital, Makkah, Saudi-Arabia. ${ }^{2}$ Department of Dermatology, Taif University, Taif, Saudi Arabia. ${ }^{3}$ Department of Dermatology, King Abdullah Medical City, Makkah, Saudi Arabia.

Corresponding author: Dr. Khalid Al Aboud, E-mail: amoa65@hotmail.com

\begin{abstract}
Pigmented purpuric dermatoses (PPDs) are chronic benign dermatoses characterized by petechiae, purpura, and increased skin pigmentation. The hallmark of pigmented purpuric dermatoses is their orange-brown, speckled, cayenne pepper-like discoloration. It occurs, most commonly on on the lower extremities and may be asymptomatic or pruritic. The aim in this short communication is to shed some lights on the eponyms in dermatology linked to PPDs.
\end{abstract}

Key words: Dermatology, Diseases, Eponyms.

Pigmented purpuric dermatoses (PPDs), also known as capillaritis, purpura simplex, and inflammatory purpura without vasculitis, include a spectrum of vascular diseases, usually of unclear etiology [1].

Various conditions have been mentioned under this group. These include:

- Schamberg's disease

- Purpura annularis telangiectodes

- Pigmented purpuric lichenoid dermatitis of Gougerot and Blum

- Lichen aureus

-Eczematid-like purpura of Doucas and Kapetanakis

- Itching purpura

- Unilateral linear capillaritis

- Granulomatous pigmented purpura

PPDs share some common histopathological features such as red blood cells extravasation, hemosiderin deposition (mainly within the dermal macrophages), narrowing of small vessel lumen, endothelial edema and lymphocytic perivascular infiltrate [1].

Stain for hemosiderin (storage iron granules) is very useful to detect iron overload in the tissue.
Perl's iron stain (also known historically as, Perls' Prussian blue), is the classic method for demonstrating iron in tissues. The section is treated with dilute hydrochloric acid to release ferric ions from binding proteins. These ions then react with potassium ferrocyanide to produce an insoluble blue compound (the Prussian blue reaction).

Hemosiderin may be present in areas of old hemorrhage or be deposited in tissues with iron overload. Hemosiderosis refers to the state in which the stored iron does not interfere with organ function. The latter is in comparison to hemochromatosis where iron overload is associated with organ failure.

Perl's iron stain is named after its inventor, German pathologist Max Perls (1843-1881).

PPDs occur predominantly in the lower limbs of adults, but can affect children. Some particular clinical aspects allow the division of PPD into eponymous variants.

In table 1 we listed eponymous conditions in dermatology linked to PPDs.

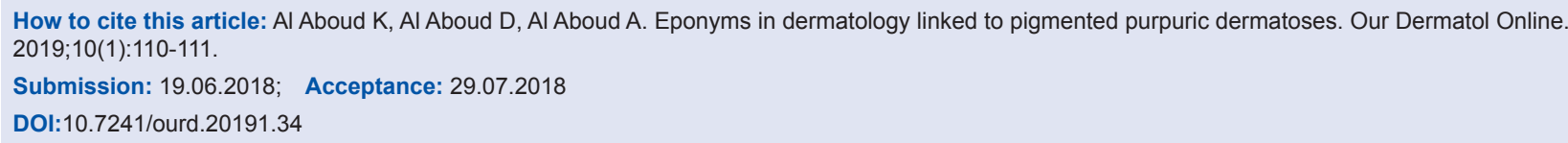


Table 1: Eponymous conditions in dermatology linked to pigmented purpuric dermatoses:

\begin{tabular}{ll}
\hline $\begin{array}{l}\text { Eponymous conditions linked to pigmented } \\
\text { purpuric dermatoses }\end{array}$ & Remarks \\
\hline Eczematid-like purpura of Doucas and Kapetanakis[2] & $\begin{array}{l}\text { It is distinguished from other forms of PPD by the concomitant presence of eczematous } \\
\text { features. Some authors have considered eczematid-like purpura of Doucas and Kapetanakis } \\
\text { and itching purpura as a single entity. }\end{array}$ \\
& $\begin{array}{l}\text { It is named for 2 Greek physicians, Christoforos Doucas (1890-1974) and loannis } \\
\text { Capetanakis (1913-1987). }\end{array}$ \\
It presents with nonblanchable, annular, 2 to 20 cm, symmetrical, purpuric, telangiectatic \\
patches.
\end{tabular}

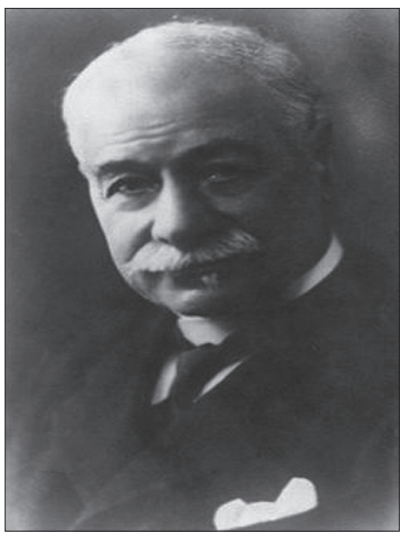

Figure 1: Domenico Majocchi (1849-1929).

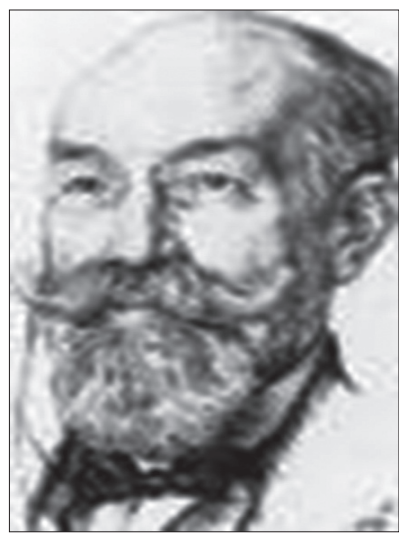

Figure 2: Henri Gougerot (1881-1955).

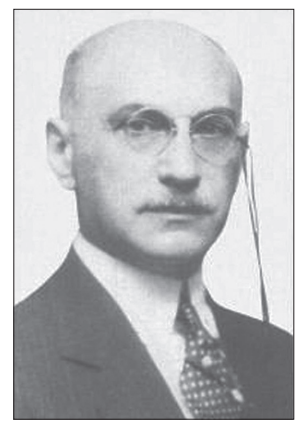

Figure 3: Jay Frank Schamberg (1870-1934).

\section{REFERENCES}

1. Cavalcante MLLL, Masuda PY, Brito FF, Pinto ACVD, Itimura G, Nunes AJF. Schamberg's disease: case report with therapeutic success by using colchicine. An Bras Dermatol. 2017;92:246-8.

2. Al Aboud $\mathrm{K}, \mathrm{Al}$ Aboud A.Eponyms in the dermatology literature linked to Greece. Our Dermatol Online. 2013;4(Suppl. 2):435-6.

3. Brzezinski P, Bourée P, Chiriac A, Bouquot JE, Schepis C, Hofer T, et al. Dermatology Eponyms - Sign - Lexicon - (M). Our Dermatol Online. 2014;5:312-26.

4. $\mathrm{Al}$ Aboud $\mathrm{A}, \mathrm{Al}$ Aboud $\mathrm{K}$. A mini-review on eponyms in the dermatology literature linked to France. Our Dermatol Online. 2013;4(Suppl. 2):440-3.

5. Al Aboud A, Al Aboud K.A mini-review on eponyms in the dermatology literature linked to United States of America (USA). Our Dermatol Online. 2013;4(Suppl. 1):409-13.

Copyright by $\mathrm{M}$ Khalid Al Aboud, et al. This is an open-access article distributed under the terms of the Creative Commons Attribution License, which permits unrestricted use, distribution, and reproduction in any medium, provided the original author and source are credited.

Source of Support: Nil, Conflict of Interest: None declared. 